\title{
Comparative genomics of Cylindrospermopsis raciborskii strains with differential toxicities
}

\author{
Rati Sinha', Leanne A Pearson'1, Timothy W Davis², Julia Muenchhoff', Ryanbi Pratama', Aaron Jex³,
} Michele A Burford ${ }^{2}$ and Brett A Neilan ${ }^{1 *}$

\begin{abstract}
Background: Cylindrospermopsis raciborskii is an invasive filamentous freshwater cyanobacterium, some strains of which produce toxins. Sporadic toxicity may be the result of gene deletion events, the horizontal transfer of toxin biosynthesis gene clusters, or other genomic variables, yet the evolutionary drivers for cyanotoxin production remain a mystery. Through examining the genomes of toxic and non-toxic strains of $C$. raciborskii, we hoped to gain a better understanding of the degree of similarity between these strains of common geographical origin, and what the primary differences between these strains might be. Additionally, we hoped to ascertain why some cyanobacteria possess the cylindrospermopsin biosynthesis (cyr) gene cluster and produce toxin, while others do not. It has been hypothesised that toxicity or lack thereof might confer a selective advantage to cyanobacteria under certain environmental conditions.

Results: In order to examine the fundamental differences between toxic and non-toxic C. raciborskii strains, we sequenced the genomes of two closely related isolates, CS-506 (CYN $)$ and CS-509 (CYN) sourced from different lakes in tropical Queensland, Australia. These genomes were then compared to a third (reference) genome from C. raciborskii CS-505 $\left(\mathrm{CYN}^{+}\right)$. Genome sizes were similar across all three strains and their $\mathrm{G}+\mathrm{C}$ contents were almost identical. At least 2,767 genes were shared among all three strains, including the taxonomically important rpoc1, ssURNA, IsURNA, $c p C A, c p c B$, nifB and nifH, which exhibited 99.8-100\% nucleotide identity. Strains CS-506 and CS-509 contained at least 176 and 101 strain-specific (or non-homologous) genes, respectively, most of which were associated with DNA repair and modification, nutrient uptake and transport, or adaptive measures such as osmoregulation. However, the only significant genetic difference observed between the two strains was the presence or absence of the cylindrospermopsin biosynthesis gene cluster. Interestingly, we also identified a cryptic secondary metabolite gene cluster in strain CS-509 (CYN) and a second cryptic cluster common to CS-509 and the reference strain, CS-505 $\left(\mathrm{CYN}^{+}\right)$.
\end{abstract}

Conclusions: Our results confirm that the most important factor contributing to toxicity in C. raciborskii is the presence or absence of the cyr gene cluster. We did not identify any other distally encoded genes or gene clusters that correlate with CYN production. The fact that the additional genomic differences between toxic and non-toxic strains were primarily associated with stress and adaptation genes suggests that CYN production may be linked to these physiological processes.

Keywords: Cylindrospermopsis raciborskii, Cylindrospermopsin, Cyanobacteria, Comparative genomics

\footnotetext{
* Correspondence: b.neilan@unsw.edu.au

${ }^{1}$ School of Biotechnology and Bimolecular Sciences, University of New South

Wales, 2052 Sydney, NSW, Australia

Full list of author information is available at the end of the article
}

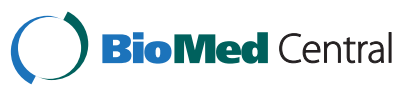

(c) 2014 Sinha et al.; licensee BioMed Central Ltd. This is an Open Access article distributed under the terms of the Creative Commons Attribution License (http://creativecommons.org/licenses/by/2.0), which permits unrestricted use, distribution, and reproduction in any medium, provided the original work is properly cited. The Creative Commons Public Domain Dedication waiver (http://creativecommons.org/publicdomain/zero/1.0/) applies to the data made available in this article, unless otherwise stated. 


\section{Background}

Cyanobacteria are photosynthetic prokaryotes that thrive in a wide variety of habitats. Their occurrence in aquatic environments is of particular interest due to their ability to form dense and potentially toxic blooms under certain environmental conditions [1,2]. Some of the toxins produced include cyclic hepatotoxic peptides such as microcystin and nodularin [3], alkaloids such as the cytotoxic cylindrospermopsin (CYN) [4] and the neurotoxic saxitoxin (STX) [5], and organophosphates, such as anatoxin-a(s) [6]. These cyanotoxins, produced by over 40 species from 20 genera of cyanobacteria [7], have adverse health effects on humans and animals, and are a public health and environmental concern [3].

The toxin CYN first came into recognition following the poisoning of 149 people on Palm Island in 1979 [8]. Since then several animal poisonings have been recorded, including cattle mortalities [9]. Interestingly, several distantly related cyanobacterial species produce CYN, including Aphanizomenon ovalisporum [10], Raphidiopsis curvata [11], Oscillatoria sp. PCC 6506 [12], Anabaena lapponica [13], Lyngbya wollei [14], Umezakia natans [15], Raphidiopsis mediterranea [16], Anabaena bergii [17] and Cylindrospermopsis raciborskii [18].

C. raciborskii, a filamentous diazotrophic cyanobacterial species, is a known producer of both cylindrospermopsin and saxitoxin [18], with the type of toxin produced apparently linked, in part, to geographic distribution. Although STX-producing C. raciborskii strains have been reported in South America [19], based on the current understanding, the most broadly distributed toxigenic members of this species produce CYN [20], with $\mathrm{CYN}$ producers $\left(\mathrm{CYN}^{+}\right)$having been reported in Australia, Asia, and New Zealand [21]. Additionally, $C$. raciborskii strains containing some $c y r$ and $s x t$ (saxitoxin biosynthesis) genes have also been found in South America, although these strains were found to be nontoxic [22]. There is mounting evidence for the global emergence of $C$. raciborskii, with the species exhibiting an increasingly cosmopolitan distribution. C. raciborskii was initially identified in tropical climatic regions, however, reports of its occurrence in temperate zones have increased drastically in the last decade [20,23-25].

Although the production of CYN and STX by cyanobacteria is well characterized and relates primarily to the presence of toxin-specific biosynthetic gene clusters $[26,27]$, the mechanism for acquisition/loss of toxin gene clusters between and among closely related strains of $C$. raciborskii or a variety of distantly related cyanobacteria species [28] is not understood. It is also not known, which, if any, genes associated with the cyr gene cluster might be lost without loss of toxigenicity. Although a representative genome has been published for a toxigenic strain of $C$. raciborskii [19] there has been no large-scale characterization of the genome of other members of the species, or, specifically between and among toxic and non-toxic strains. Such comparisons may provide insight into how toxin clusters are shared/ inherited, whether the differences between being toxic or non-toxic strains relates to a loss (e.g. through gene loss or mutational change) or gain (e.g. through cluster acquisition) of function, and what additional differences may exist between the genomes of toxic and non-toxic Cylindrospermopsis strains.

In the present study we conducted genome-wide comparisons of two closely related, but toxicologically distinct strains, CS-506 $\left(\mathrm{CYN}^{+}\right)$and CS-509 $\left(\mathrm{CYN}^{-}\right)$, of $C$. raciborskii isolated from the same geographical region of Queensland, Australia and compared these with the published genome of the $\mathrm{CYN}^{+}$C. raciborskii CS-505 [19]. A primary aim of this study was to elucidate the minimal set of genes required for CYN production and explore whether or not this genomic locus extends beyond the cyr cluster. We also hoped to ascertain if toxin production influences the overall physiology of CS-506, by examining the putative metabolic roles of strainspecific genes. Our results are discussed within the context of the evolution and ecophysiology of these closely related cyanobacterial strains.

\section{Methods}

\section{Cyanobacterial strains and culturing}

C. raciborskii strains CS-506 and CS-509 were originally isolated from the Queensland waterbodies Solomon Dam $\left(8.7242^{\circ} \mathrm{S} 146.594^{\circ} \mathrm{E}\right)$ in 1996 and Lake Julius $\left(20.1315^{\circ} \mathrm{S}\right.$ $\left.139.723^{\circ} \mathrm{E}\right)$ in 1995 , respectively. Detailed toxin and morphotype analyses of strains CS-506 and CS-505 were conducted in a previous study in which they were referred to as 'form 1' and 'form 2', respectively [29]. For the present study, strains were obtained from the Australian National Algae Culture Collection (ANACC), CSIRO Marine and Atmospheric Research, Hobart, Tasmania. Non-axenic cultures of these strains were grown in $250 \mathrm{ml}$ culture flasks in Jaworski medium (JM) [30] at $25^{\circ} \mathrm{C}$, under a light intensity of 25-30 $\mu \mathrm{mol}$ photons $\mathrm{m}^{-2} \mathrm{~s}^{-1}$ with a $12 \mathrm{~h}$ light/dark cycle.

\section{DNA extraction and quality control}

To harvest cells, dense $250 \mathrm{ml}$ cultures were filtered onto $3 \mu \mathrm{m}$ pore size nitrocellulose membranes and washed with 2 volumes of JM to reduce contaminating bacteria to undetectable levels by $16 \mathrm{~S}$ PCR (see below). High molecular weight DNA was extracted as previously described [31]. Briefly, cells were lysed with lysozyme and treated with proteinase $K$. The resulting lysate was then treated with $20 \%$ sodium dodecyl sulphate and cetyl trimethylammonium bromide and extracted with phenol/chloroform. DNA was precipitated with 2 volumes of ethanol, and 0.1 volume of $3 \mathrm{M}$ sodium acetate then 
washed twice with 70\% ethanol. Each sample was incubated at $4^{\circ} \mathrm{C}$ for $12-24 \mathrm{~h}$ to allow RNA degradation to occur and DNA quality was assessed spectrophotometrically and by gel electrophoresis. Only high molecular weight pure DNA samples were used for sequencing. DNA samples with a $260 / 280 \mathrm{~nm}$ absorbance ratio of $1.8-2.0$, and a $260 / 230 \mathrm{~nm}$ absorbance ratio of $1.8-2.0$ were considered pure.

The DNA samples were further quality-checked by amplification of the $16 \mathrm{~S}$ rRNA gene by PCR. Primers specifically targeting the cyanobacterial 16S rRNA gene (27FL/809R), and bacterial 16S rRNA gene (27FL/1494R) [32] were used to this end. PCR was performed using the following conditions: initial denaturation at $94^{\circ} \mathrm{C}$ for $2 \mathrm{~min}$, followed by 30 cycles of denaturation at $94^{\circ} \mathrm{C}$ for $30 \mathrm{~s}$, annealing at $55^{\circ} \mathrm{C}$ for $30 \mathrm{~s}$, extension at $72^{\circ} \mathrm{C}$ for $1 \mathrm{~min}$, then a final extension at $72^{\circ} \mathrm{C}$ for $30 \mathrm{~s}$. The resulting amplicons were sequenced using the BigDye Terminator kit (Invitrogen) and analyzed using Bioedit [33]. DNA samples that yielded pure C. raciborskii $16 \mathrm{~S}$ rRNA gene sequences were finally submitted for genome sequencing. These steps ensured that all $C$. raciborskii DNA samples used for genome sequencing were free from contaminating heterotrophic bacterial DNA.

\section{Genome sequencing and comparative analyses}

Paired-end indexed libraries were prepared from purified DNA fragments of approximately 320 bp in length. Genome sequencing was performed using the Genome Analyzer IIx sequencing platform and TruSeq SBS v4 GA kit. The raw reads generated were $100 \mathrm{bp}$ in length. Raw read quality was visualized using FastQC software (Babraham Bioinformatics) with default settings. All raw reads were filtered for quality (mean phred $>20$ ) and endtrimmed (10 bp at $5^{\prime}$ and $3^{\prime}$ ) using custom Perl scripts. Paired-reads passing these quality filters were used to estimate the genome size for each strain using the program khmerfreq [34] using kmer $=17$ and then assembled using SOAPdenovo software [34] with different kmer lengths (57-64), with the final assembly selected based on overall assembly size, number of contigs and contig size.

The optimal assemblies for C. raciborskii CS-506 and CS-509 were annotated using homology-based (Integrated Microbial Genomes (IMG) [35] and Rapid Annotations Subsystems Technology (RAST) [36]) and predictive modeling (Glimmer [37], Genemarks [38]) approaches. We used the published genome of the CYN-producing C. raciborskii strain CS-505 [19], also isolated from Solomon Dam, Queensland, Australia, as a reference genome for comparative assessment of these annotation methods. Glimmer 3 and Genemarks vastly overestimated gene number, when compared to the previously published reference genome for $C$. raciborskii strain CS-505. For ease of annotation, and to be consistent with the prediction of CS-505 genes, RAST was used for the final analysis. NRPS-PKS predictor [39] and antiSMASH [40] software were used to identify nonribosomal peptide synthetase (NRPS) and polyketide synthase (PKS) domains. Additionally, further annotation of genes encoding hypothetical proteins was conducted using the program InterProScan [41] or the pfam database [42].

Following annotation of each genome, we conducted pair-wise comparisons of the gene-sets predicted for each strain using BLASTn [43]. Genes were considered common to two taxa in pair-wise comparisons if reciprocal BLAST hits had (a) an e-value $\leq 1^{*} 10^{-5}$, (b) $\geq 90 \%$ nucleotide identity and (c) a difference between query and alignment length of $\leq 20 \mathrm{bp}$. Genes not meeting these criteria in any pair-wise comparison were considered strain-specific. To ensure that genes 'missing' from each strain based on these BLASTn comparisons were not absent due to gaps in the assembly or misannotation, we mapped the filtered reads from both CS-506 and CS-509 to the published CS-505 sequence using the program SOAPAligner [44]. The bioinformatic prediction of these strain-specific genes was further tested using PCR for a subset of sequences $(\mathrm{n}=13$; Additional file 1). Briefly, primers targeting genes that were absent from only one of the three $C$. raciborskii strains, CS505 , CS-506 or CS-509, were designed using primerBLAST (NCBI). PCR was performed using the following conditions: initial denaturation at $94^{\circ} \mathrm{C}$ for $2 \mathrm{~min}$, followed by 30 cycles of denaturation at $94^{\circ} \mathrm{C}$ for $30 \mathrm{~s}$, annealing at $59^{\circ} \mathrm{C}$ for $30 \mathrm{~s}$, extension at $72^{\circ} \mathrm{C}$ for $1 \mathrm{~min}$, and a final extension at $72^{\circ} \mathrm{C}$ for $30 \mathrm{~s}$. Suitable positive and negative controls were used in all PCR experiments and approximately $20 \mathrm{ng}$ of template DNA was used in each reaction. Amplicons were visualized using an agarose gel electrophoresis unit. 1\% agarose in TAE gels were stained in ethidium bromide and subsequently viewed using a UV transilluminator. Amplification of an expected size PCR product was used to confirm the presence of a gene.

Structural and overall nucleotide variation between and among C. raciborskii CS-505, CS-506 and CS-509 genomes was assessed at the whole genomic level by comparative alignment using the '-nucmer' (--maxmatch) and 'dnadiff' packages of the program Mummer 3 [45]. Specific nucleotide variation between and among protein-encoding genes and within non-coding regions was assessed by comparative alignment of each genome using the Smith-Waterman alignment algorithm of the program Burrows-Wheeler Aligner (BWA: [46]). Genes common to all three C. raciborskii strains were each aligned as orthologous clusters using Muscle [47] and the alignments assessed for synonymous, non-synonymous and indel mutations. To ensure only high-confidence single nucleotide polymorphisms (SNPs) were included in our analysis, we mapped the raw 
reads for each sample to its respective assembly (using Bowtie2) [48] and filtered the initial SNP calls using the Neighbor-Quality Scoring method [49] in which only SNPs covered to a depth $\geq 5$ with reads having a phred mapping quality of $\geq 20$ and flanked to the $5^{\prime}$ and $3^{\prime}$ by at least 3 bases with a phred mapping quality of $\geq 15$ were retained for subsequent analysis. Read mapping quality was assessed using Samtools v 0.1.19 [50]. Using these SNP data, various population genetic metrics ( e.g. segregating sites, synonymous and non-synonymous SNPs per bp) were calculated using custom-perl scripts.

The data sets supporting the results presented in this manuscript are available in the following repository: Integrated Microbial Genomes [IMG] repository, unique persistent identifier 12992 and 12991 and NCBI short read archive under accession numbers: SRR1042336 and SRR1041118 for C. raciborskii strains CS-506 and CS509 , respectively.

\section{Results and discussion Genomic structure}

The genomes of $C$. raciborskii strains CS-506 and CS509 were sequenced via the bridge amplification method on an Illumina genome analyzer. Both genomes were sequenced to a depth of $\sim 828$ and 459 fold, respectively. The total assembly size for each genome was $4.1 \mathrm{Mb}$ ( N50 $=25,000 \mathrm{bp}$; total scaffolds 698) for strain CS-506 and 4.0 Mb (N50=56,411 bp; total scaffolds 319) for CS-509 (Table 1), which is comparable to that of the reference strain, CS-505 $(3.9 \mathrm{Mb})$. The largest scaffolds assembled were 67,497 bp for CS-506 and 188,708 bp for CS-509. Overall, the draft assemblies for strains CS-506

Table 1 Genome assembly statistics of the three strains

\begin{tabular}{|c|c|c|c|}
\hline \multirow[t]{2}{*}{ Genome characteristics } & \multicolumn{3}{|c|}{ C. raciborskii strain } \\
\hline & CS-506 & CS-509 & CS-505 \\
\hline Size $(M b)$ & 4.1 & 4.0 & 3.9 \\
\hline $\mathrm{G}+\mathrm{C}$ content $(\%)$ & 41.1 & 40.7 & 40.8 \\
\hline N50 (bp) & 25,000 & 56,411 & NA \\
\hline N90 (bp) & 412 & 268 & NA \\
\hline Largest scaffold (bp) & 67,497 & $1,88,708$ & $2,59,000$ \\
\hline Scaffolds $>10 \mathrm{~kb}$ & 103 & 65 & NA \\
\hline Scaffolds $>40 \mathrm{~kb}$ & 8 & 19 & NA \\
\hline Scaffolds > $100 \mathrm{~kb}$ & 0 & 5 & NA \\
\hline $\operatorname{CDS}^{*}$ & 3,268 & 3,416 & 3,452 \\
\hline Unique $\mathrm{CDS}^{*}$ & 176 & 101 & 181 \\
\hline Common CDS* & 2,767 & 2,767 & 2,767 \\
\hline rRNA genes* & 8 & 6 & 9 \\
\hline tRNA genes* & 44 & 40 & 42 \\
\hline Genes with functional annotations (\%) & 36 & 34 & 55 \\
\hline
\end{tabular}

$\mathrm{N} 50$, largest contig size, and other information relevant to the assembly of the genomes. NA = Data not available, $\mathrm{CDS}=$ coding sequence,${ }^{*}$ Total number. and CS-509 yielded 103 and 65 scaffolds $>10 \mathrm{~kb}, 8$ and 19 scaffolds $>40 \mathrm{~kb}$, and 0 and 5 scaffolds over $100 \mathrm{~kb}$, respectively. The $\mathrm{G}+\mathrm{C}$ content of both genomes was similar (approximately $40.9 \%$ ) and comparable to that of the reference strain (40.2\%), as well as other filamentous cyanobacterial genomes i.e. Raphidiopsis sp. [28] and Anabaena sp. presently available in the public databases (40-41.5\%) (NCBI). In the absence of a physical map for these genomes, structural variation among the assemblies was interpreted with some caution. Nonetheless, based on pair-wise comparisons, CS-505 $\left(\mathrm{CYN}^{+}\right)$and CS-509 $\left(\mathrm{CYN}^{-}\right)$show a higher level of structural synteny as compared to CS-506 $\left(\mathrm{CYN}^{+}\right)$(Additional file 2). Overall the CS-509 assembly could be aligned in syntenic blocks with $>95 \%$ of the CS-505 assembly, whereas CS506 showed alignment synteny with only $93.6 \%$ of this genome. The CS-506 assembly, relative to the CS-505 genome, also contained a larger number of breakpoint $(8,315)$, translocation $(1,111)$, insertion $(2,846)$ and tandem insertion (9) events than the pair-wise alignment of CS-509 and CS-505, further evidence of the greater similarity between the CS-505 and CS-509 genomes, compared to the similarity between the toxic strains CS505 and CS-506. The CS-509 assembly, in comparison contained 8,036 breakpoint, 927 translocation, 2,539 insertion and 5 tandem insertion events.

CS-505 and CS-509, contrary to their different toxic phenotypes, were also significantly more similar in sequence than CS-505 and CS-506, with 8,200 SNPs $(72.8 \%$ in coding regions) and 13,405 SNPs (75.8\% in coding regions) observed between the genomes of these pairs respectively. Based on multiple pair-wise alignment of the three C. raciborskii genomes, we established an orthologous relationship among all three strains for 2,917 of the 3,418 protein coding genes annotated for CS-505 [19]. Comparative alignment of these assemblies revealed 99.5\% nucleotide identity (representing 3,599,169 alignable bases) among all three strains (Additional file 3). For these orthologous genes, we detected 9,460 (3.3 per kb) and 4,766 (1.8 per kb) SNPs between CS-505 and CS-506 and between CS-505 and CS509 , respectively, relating to a mean nt identity of 99.6 and $99.8 \%$, respectively. Notably, among the genes found to be identical among all three strains were rpoc1 (RNA polymerase subunit), $c p c A$ and $c p c B$ (phycocyanin alpha and beta subunits) and nifB and nifH (nitrogen fixation proteins), all of which are widely utilized for phylogenetic analyses of cyanobacteria. In a separate analysis, we also noted $99.8 \%$ sequence identity among ssuRNA and lsuRNA (small and large subunits of ribosomal RNA). Hence, although these loci have proven useful for the molecular classification of cyanobacteria to the species level, our results suggest that they are not useful for differentiating $C$. raciborskii strains. Some of the more variable genes under low mutational selective pressure based on the accumulation of coding 
(i.e., non-synonymous) to non-coding (i.e., synonymous) SNPs for both CS-506 and CS-509 that may be worthy of further exploration as intra-specific markers for Cylindrospermopsis are a putative Random Associated Mysterious Protein (RAMP) superfamily protein, CRC_01868 (3.7 and $4.1 \%$ nt variability for CS-506 and CS-509, respectively), a hemolysin A homolog, CRC_02719 (3.4 and 4.9\% variability) and a HAD-superfamily hydrolase, CRC_00377 (3.4 and $2.1 \%$ variability).

Interestingly, a large proportion of the differences between CS-506 and CS-509 in the shared, orthologous genes related to non-synonymous (NS) mutations, with these being more than twice as common in the former ( $\mathrm{n}=5,971$ SNPs) than the latter $(\mathrm{n}=2,419)$ relative to CS-505. By contrast, synonymous (S) SNPs in these orthologous genes were relatively equal in number between the two strains (2,495 and 2,054 for CS-506 and CS-509, respectively). The higher rate of NS SNPs in these genes between CS-506 and CS-505 in comparison to CS-509 and CS-505 may be suggestive of significant differences in the ecological niches of or selective pressures on CS-505 and CS-506 despite their shared toxic phenotype and the close proximity of their geographic origin.

In addition to these alignment based comparisons, we independently assessed the gene composition and putatively identified functional differences between the three strains using RAST [51]. This approach also allowed identification of novel genes encoded in either CS-506 or CS-509 but not found in CS-505. Based on RAST prediction, the CS-506 and CS-509 assemblies were predicted to encode 3,268 and 3,416 protein encoding genes, respectively (see Table 1), compared to the 3,452 currently annotated for CS-505 [19]. With RAST identifying 2,767 of these CDS to be shared as homologs among all three $C$. raciborskii strains, CS-506, CS-509 and CS-505 (Figures 1 and 2), representing 82\%, 84.8\% and $81.8 \%$ of all predicted CDS, respectively.

\section{Conservation among C. raciborskii predicted metabolomes}

The genes shared between/among all three $C$. raciborskii strains included those associated with key metabolic pathways, such as photosynthesis, nitrogen and phosphorus metabolism. Many of these pathways appear to be highly conserved across the three $C$. raciborskii strains and are also similar to primary metabolic pathways identified in other species of cyanobacteria [52-54]. Although all core genes required for photosynthesis in cyanobacteria [52] were present in each $C$. raciborskii strain, these genes were distributed among eight distinct operons (e.g. psaAB, psbCD, petCA, petBD, atpIHGFDAC, coxBAC, chlDHI and $\operatorname{ch}(N B L)$. This arrangement of photosynthesis genes as eight separate operons is also found in other cyanobacteria, including Nostoc punctiforme ATCC 29133 [53],

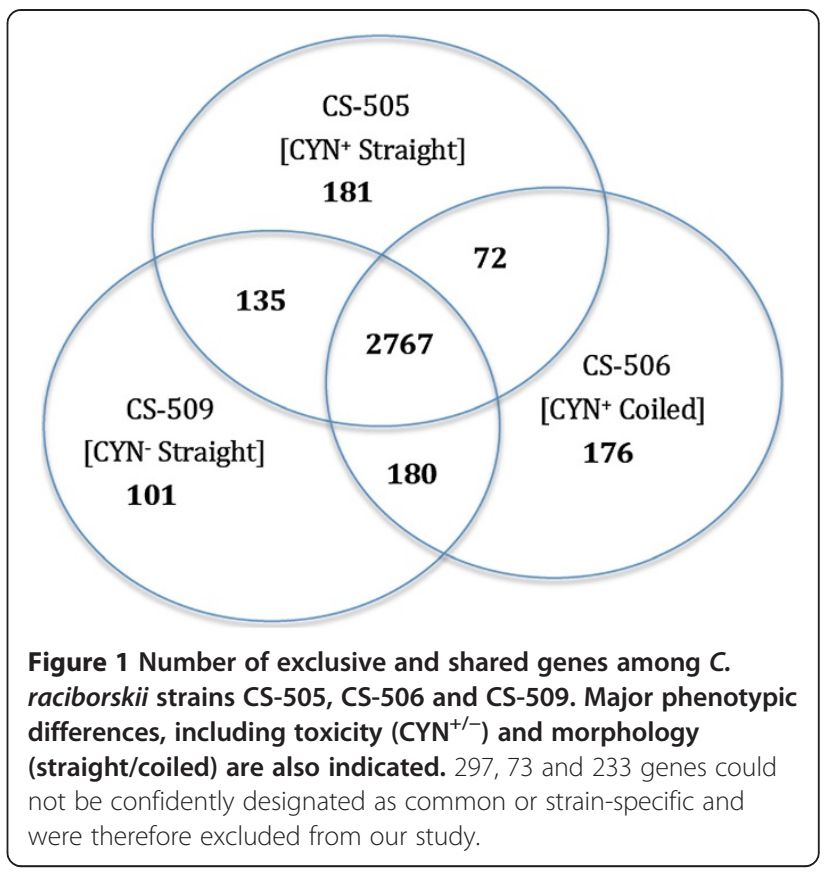

Raphidiopsis curvata, and Raphidiopsis mediterranea but distinct from related, non-cyanobacterial species, such as Rhodobacter sphaeroides, which organize their photosynthesis genes into a single operon [55]. It is possible that one long continuous photosynthesis gene cluster is ancestral in the bacteria, with subsequent genomic rearrangement into separate operons occurring more recently in some taxa.

Nitrogen metabolism genes, including those for nitrogen fixation, ammonium, nitrate and nitrite assimilation and heterocyst development were also conserved among CS-505, CS-506, and CS-509. These genes clustered into several distinct operons, including those for nitrogenase (nifB, $f d x N$, nifS, nifU, nifH, nifD, nifK, ORF, nifE, nif $N$, nifX, ORF, ORF, nifW, hes $A$, hes $B, f d x H)$, and nitrite/ nitrate uptake and reduction (nirA, nrtA, nrtB, nrtC, $n r t D$, narB). Such operons have been described in other cyanobacteria, including $N$. punctiforme ATCC 29133, Anabaena PCC 7120, A. variabilis ATCC 29413 [56], and $A$. variabilis PCC 7120 [57].

We also observed the presence of an identical set of phosphorus metabolism genes, displaying high synteny in all three strains. These comprise the pho regulon (phoU, phoR, phoB, pstA, pstB, pstC and pstS), inorganic phosphatase, transhydrogenases (subunits alpha and beta) and alkaline phosphatases, and are required for phosphorus metabolism [54]. The genes pstA, pstC and pst $B$ form one cluster while the histidine kinase phoR and the transcriptional regulator phoB form another. A similar arrangement of phosphorus metabolism genes has been observed in the genomes of Microcystis aeruginosa PCC 7806 [58] and Raphidiopsis mediterranea. 


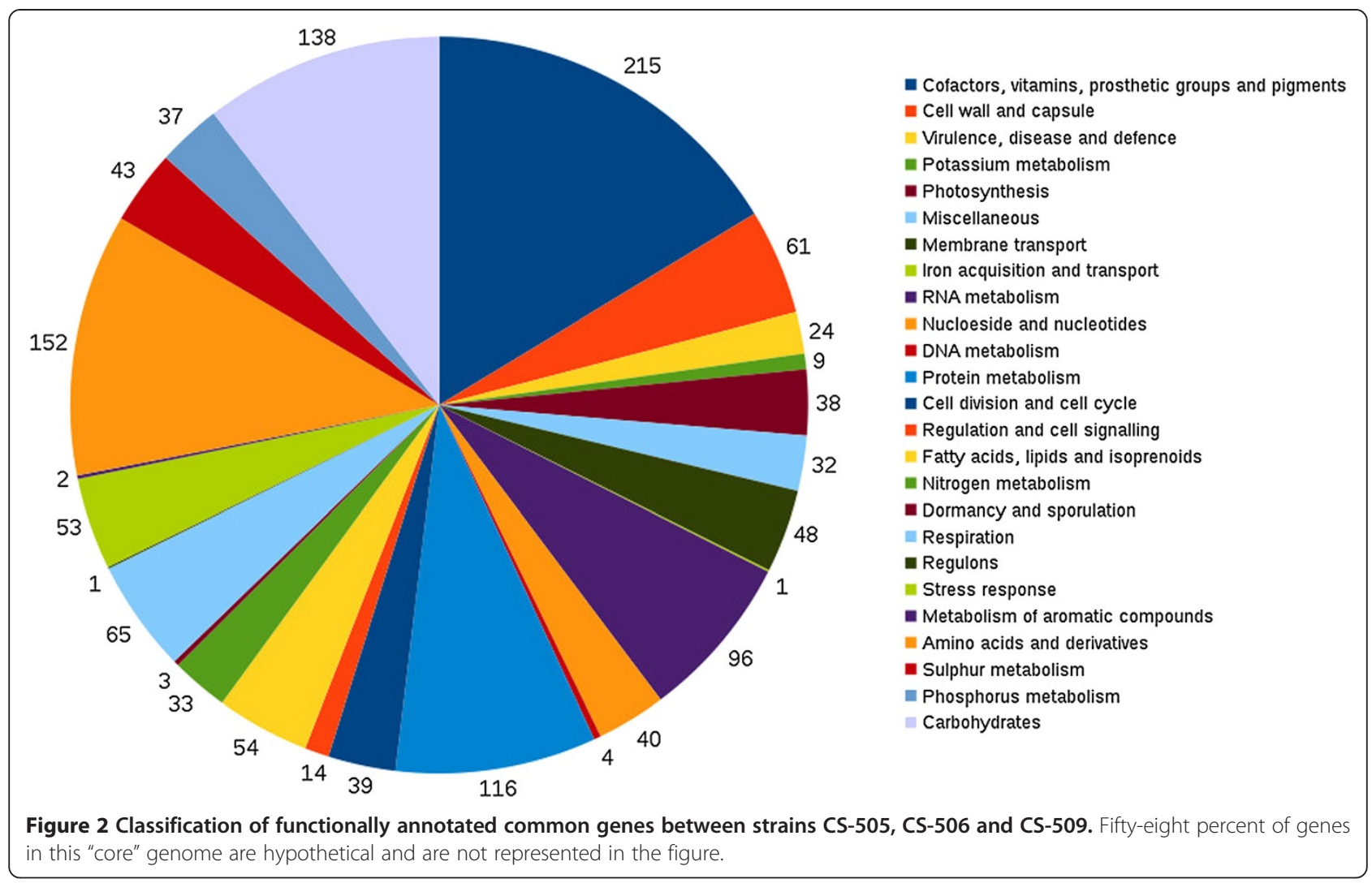

\section{Substantial differences in transporters among \\ C. raciborskii strains}

$\mathrm{ABC}$ transporters facilitate the translocation of ions or macromolecules across biological membranes, including the export of substances toxic to the cell [59]. Relative to CS-506 and CS-509, CS-505 was enriched for genes involved in transport, export, and nutrient uptake. The CS-505 genome encodes for a large number of ATP Binding Cassette $(\mathrm{ABC})$ transport-related genes, comprising $4.1 \%$ of its total genome. In contrast, $\mathrm{ABC}$ transporter genes comprised only 2.3 and $2.4 \%$ of the total genes in CS-506 and CS-509, respectively. The enrichment of $\mathrm{ABC}$ transporters in CS-505 was mainly limited to those responsible for the transport of glycerophospholipids [34,60], with 24 of these genes present exclusively within this strain. The strain-specific nature of these specialized $A B C$ transporters suggests a specific ecological adaptation that is not explicitly linked to CYN production, but may relate to membrane structure and permeability. The number of $\mathrm{ABC}$ transporters in other cyanobacteria was found to be significantly lower, for example in Nostoc punctiforme ATCC 29133, ABC transporters comprise only $0.03 \%$ of the genome [53]. Similarly, RAST analyses revealed that in $M$. aeruginosa $\mathrm{ABC}$ transporters comprise a mere $0.002 \%$ of the genome [51]. Other transport-related genes identified in our study strains include amino acid, $\mathrm{N}$-acetylglucosamine related, energy-coupling bacterial, and tripartite ATPindependent periplasmic (TRAP) transporters, all of which were found in consistent, but low, numbers $(<1 \%)$.

\section{Strain-specific genes}

Five percent of all genes in CS-506 were specific to this toxic strain (although $4.1 \%$ of these were annotated as hypothetical proteins). Similarly, $2.9 \%$ and $5.2 \%$ of all genes in CS-509 $\left(\mathrm{CYN}^{-}\right)$and CS-505 $\left(\mathrm{CYN}^{+}\right)$, respectively, were strain-specific (1.7\% and $3.5 \%$ of these were hypothetical). The strain-specific genes identified seemed to be largely associated with environmental response and adaptation, particularly for phage counteraction, recombination, DNA repair, transport and nutrient uptake, and stress (Figure 3). Interestingly, although a similar number of DNA repair genes were present in all the three strains (approximately $0.9-1 \%$ of their genomes), the three gene sets involved in this process were not identical. Approximately $15 \%$ of the total DNA repair related genes in CS-509 were strainspecific, whereas $7.2 \%$ of all DNA repair-related genes in strains CS-505 and CS-506 were unique to those strains. Many of these genes were found in multiple loci. The genome of the CYN-producing strain CS-505 was also enriched with interspaced short palindromic repeats (CRISPR) related genes, which comprised $0.6 \%$ of its total genome. CRISPR systems are defence machineries used by 


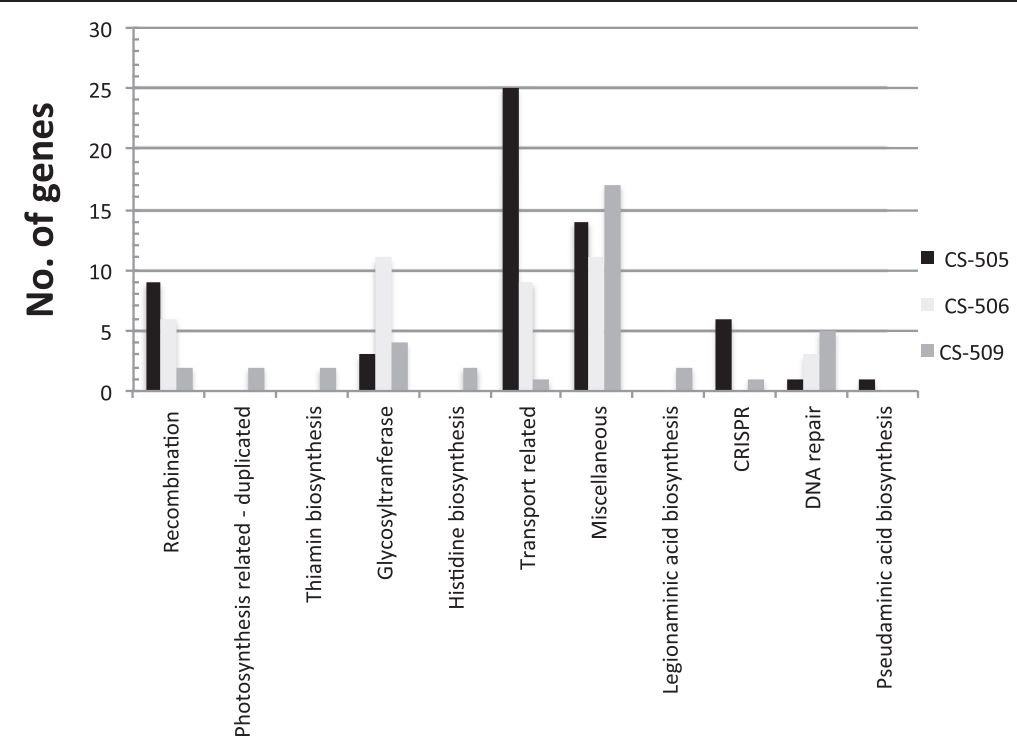

Gene categories based on function

Figure 3 Classification of strain-specific genes in the study strains possibly associated with ecophysiological adaptations. Miscellaneous category represents peptidases, proteases, methyltransferases, and and folate, thiamin and cell wall biosynthesis.

bacteria and archaea against bacteriophage [61]. In comparison, CS-506 and CS-509 contained between 0.3-0.46\% CRISPR related genes in their genomes. Strain CS-505 also contained an additional set of cas 1,2 genes containing a CRISPR locus, not present in its counterparts.

The presence of strain-specific genes and proteins has been observed in other cyanobacterial genomes and proteomes. For example, a comparative proteomic analysis of six toxic and non-toxic Microcystis aeruginosa strains reported a large diversity in the protein expression profiles of each strain, with a significant proportion of the identified proteins appearing to be strain-specific. The study found that strains of $M$. aeruginosa species differ in adaptation-related processes, rather than metabolic ones. Additionally, no protein produced exclusively by toxic or non-toxic strains was found, including the Mcy proteins responsible for microcystin biosynthesis [62]. The observed proteome diversity led to the conclusion that $M$. aeruginosa strains are ecotypes adapted to survival in a particular environmental niche rather than phylogenetically distinct subgroups. Likewise, our data suggests that strains CS-505, CS-506 and CS-509 are ecotypes adapted to specific ecological niches that exist within the same broader geographic location.

\section{Toxic strain-specific genes}

We identified 72 genes (Figure 4) common to the CYNproducing strains (CS-505 and CS-506), but absent from the non-toxic strain (CS-509). Of these, 34 were annotated as hypothetical. The cyr gene cluster (which has already been elucidated in strains AWT205 [26] and CS-
505 [19]) was identified in CS-506, but not CS-509. The cyr gene cluster encompasses $43 \mathrm{~kb}$ and encodes 15 ORFs. It comprises genes responsible for the complex biosynthesis of the CYN, namely an amidinotransferase (cyrA), a NRPS/PKS hybrid gene (cyrB), four PKS genes (cyrC, cyrD, cyrE and cyrF), amidohydrolases (cyrG and cyrH), as well as genes for tailoring reactions (cyrI, cyrJ, and $\operatorname{cyr} N)$, putative transport (cyrK), and regulation (cyrO). It also contains two transposase genes (cyrM and cyrL [26]), indicating the potential for the horizontal transfer of toxicity.

Although the genes comprising the cyr cluster appear largely conserved among CYN-producing cyanobacteria $[26,63,64]$, their location and arrangement differs between/among genera [63]. The cyr cluster in C. raciborskii CS-506 is flanked by hyp (hydrogenase pleitrophy) genes (Figure 5), which play a critical role in the maturation of hydrogenases (i.e., NiFe metalloenzymes) [65] and cluster with 20 other genes, which together are responsible for the expression of the active iron metalloenzyme. This appears to be typical for CYN-producing Cylindrospermopsis strains (e.g. AWT205 [26] and CS-505 [19]). In contrast, the cyr gene cluster in Aphanizomenon sp. is flanked by a transposase and a putative transcriptional attenuator gene [64]. The differential genomic location of the cyr cluster in various CYN-producing species suggests that the cluster may be a mobile genetic element capable of jumping between and within cyanobacterial genomes. In further support of this hypothesis, the $\mathrm{G}+\mathrm{C}$ contents of the $c y r$ gene clusters in CS-505 and CS506 (44-49\%, except cyrI 37\%) were much higher than the 


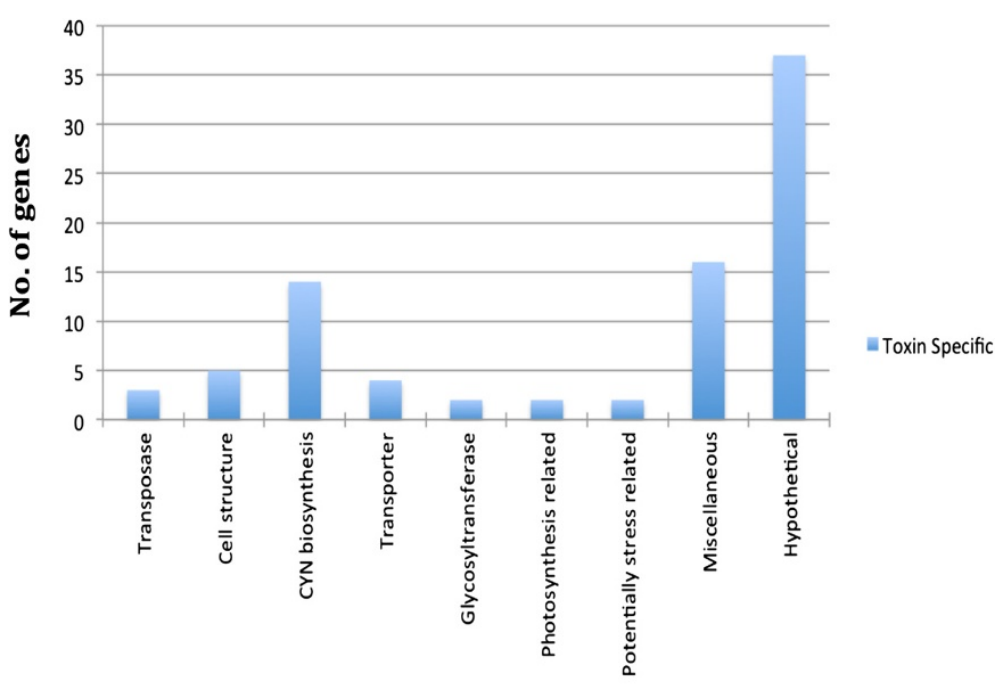

Gene categories based on function

Figure 4 Classification of toxic strain (CS-505 and CS-506)-specific genes. The miscellaneous category represents genes responsible for protein processing, sialic acid metabolism and cell division.

$\mathrm{G}+\mathrm{C}$ contents of the flanking genes (38-40\%) or of the overall genome (40-40.2\%). This finding is consistent with previous studies which showed that the $\mathrm{G}+\mathrm{C}$ content of the cyr gene cluster in Aphanizomenon sp. 10E6 was $>44 \%$, and significantly higher than for neighboring genes [66].

Although the cyr cluster was missing from CS-509, a single cyr gene, cyrO was present between the hyp genes. The precise function of CyrO remains to be determined as does its relationship to the cyr cluster. CyrO has low homology to WD repeat proteins, which have diverse regulatory signal transduction roles as well as to ATPases associated with diverse activities (AAA) family proteins which participate in chaperone like functions such as the assembly, operation and disassembly of protein complexes [26]. The $\mathrm{G}+\mathrm{C}$ content of $c y r O$ was found to be 43 , consistent with the cyr gene cluster, and higher than the flanking genes, suggesting that it may have been acquired by horizontal gene transfer or has moved from a high GC region of the genome. In contrast to its location in the $C$. raciborskii genome, cyrO in Raphidiopsis curvata D9 is separate from and distally located to the cyr gene cluster [63]. Likewise, no clear orthologs of this gene were found in CYN-producing Aphanizomenon sp. 10E6 [28]. The absence of cyrO from the cyr gene cluster or genomes of other CYN-producing species, suggests that this putative CYN regulatory protein may have an alternative function, or at least is not essential for CYNproduction.

Although the presence of the complete cyr gene cluster was the most obvious toxic strain-specific trait identified in this study, a few other genes were common to CS-505 and
CS-506, but absent from CS-509. These included genes putatively involved in transport and protein processing. The production of cyanotoxins is energetically expensive to the cell therefore the expression of additional $\mathrm{ABC}$ transporters may facilitate the uptake of nutrients required by toxic strains. Single genes responsible for cell division, cell wall capsule biosynthesis, and DNA repair were also found. Another gene, whose function in cyanobacteria has not yet been defined, was also found to be specific to the toxic strains. This gene was homologous to vanadium dependent bromopeptidases (VBPOs), which play a role in the hydrogen peroxide-dependent oxidization of halides in eukaryotes [67]. VBPOs can also act as antioxidants, removing hydrogen peroxide, a byproduct of photosynthesis detrimental to cells. In cyanobacteria, VBPOs are thought to be associated with organic compounds that infer allelopathic attributes [67] and therefore selective advantages to toxic strains.

\section{Potential mechanism for transfer, acquisition and/or loss of the cyr cluster}

A recent study comparing over twenty strains of nontoxic, STX and CYN-producing C. raciborskii, found no correlation between phylogeny and toxicity [28]. Stucken et al. 2010 suggested that the absence of toxicity in some strains of $C$. raciborskii was due to the absence or loss of the cyr cluster, rather than to point mutations or partial deletions [28]. Our results support this hypothesis and suggest that cyr genes were acquired by horizontal transfer in CS-505 and CS-506, and lost in toto from the CS509 genome. 


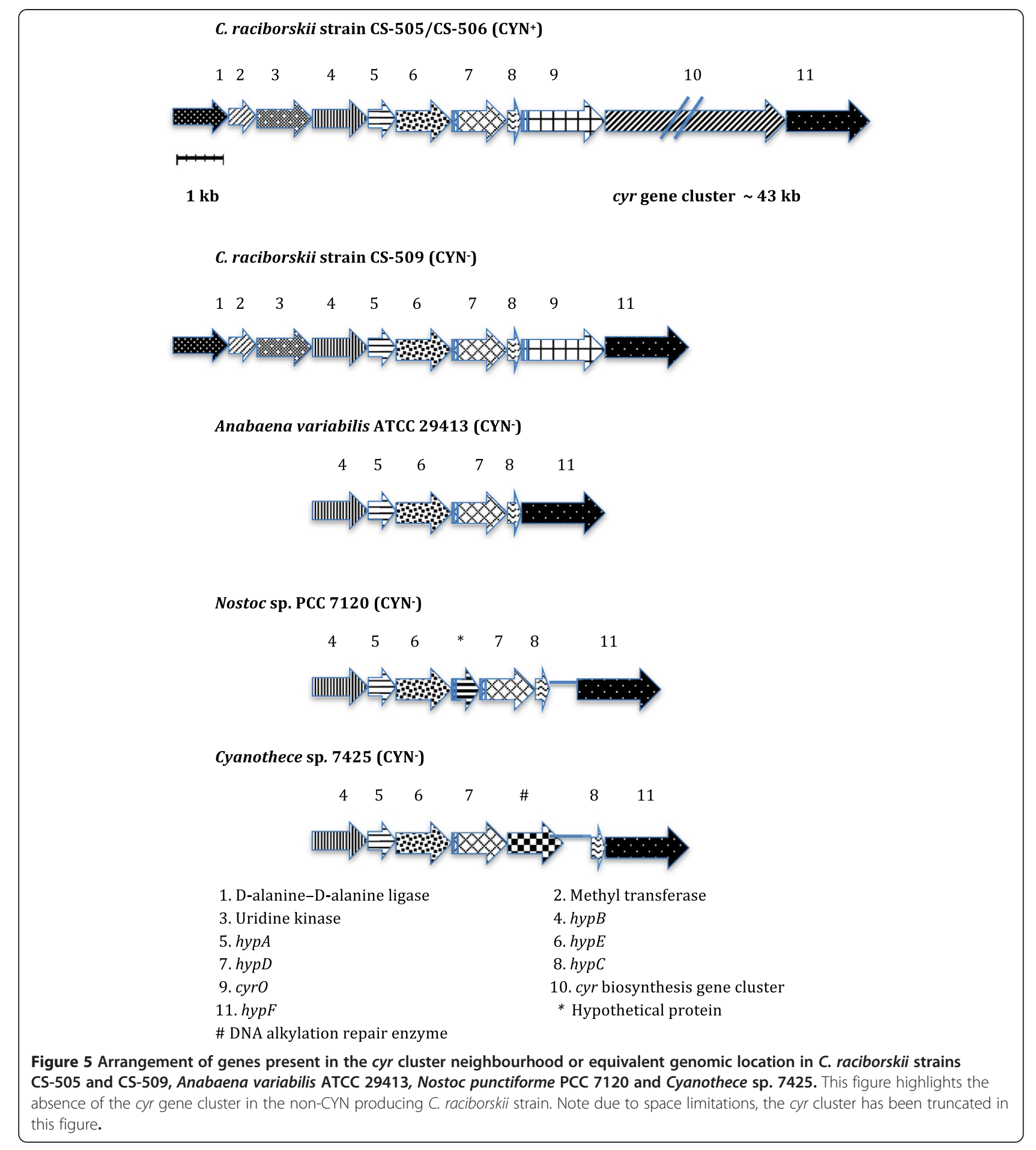

Evidence of acquired toxicity via horizontal gene transfer (HGT) and its subsequent loss has been documented for other species of cyanobacteria. For example a recent study [68] hypothesized that saxitoxin production was either gained independently via HGT in STX-producing strains, or that it was gained by a common ancestor, and lost after several generations from non-STX producers.
Genomic analysis of STX-producing Anabaena circinalis ACBU02 and a non-STX-producing ACFR02 showed that the latter strain contained four of the 26 sxt biosynthetic pathway genes, advocating the occurrence of genetic deletion. Another study examining the loss of microcystin production in Plankothrix species found that certain non-toxic strains had lost up to $90 \%$ of the 
mcy gene cluster [69]. These strains, however, still contained the genes flanking the $m c y$ gene cluster along with remnants of the transposable regions.

\section{Presence of novel metabolite clusters}

Two additional secondary metabolite clusters were detected in the $C$. raciborskii genomes examined in this study. These clusters, designated NRPS1 and NRPS2, are functionally uncharacterized at this stage (Figure 6). Cyanobacteria are producers of an array of bioactive secondary metabolites [70]. Such compounds are often produced by nonribosomal peptide synthetases (NRPS), and polyketides synthases (PKS) and are of interest due to their toxic or therapeutic properties, including antimicrobial, antifungal, or antitumor properties [70].

The cryptic NRPS1 gene cluster identified in the nontoxic C. raciborskii strain CS-509 (ORF 2370-2375) is $7,000 \mathrm{bp}$ long and encompasses 6 ORFs, including a 4,209 bp NRPS, a hypothetical protein (ORF 2373), a major family facilitator (MFS_1 gene, ORF 2372), and a sterol desaturase (ORF 2374). An incomplete NRPS1 cluster was also identified in the reference strain CS505. However, in this cluster, the NRPS gene exists as a truncated (600 bp) fragment and the MFS_1 gene is missing. Sequence-based analyses suggest that the NRPS and MFS_1 genes in the CS-509 NRPS1 cluster were acquired via HGT from a common ancestor of Anabaena

\section{cyr gene cluster}

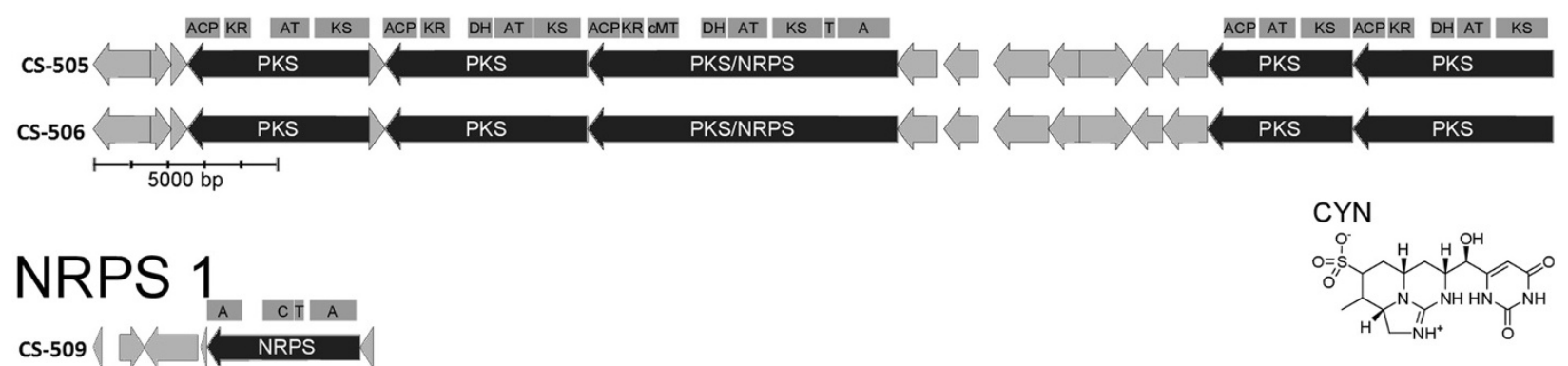

\section{NRPS 2}
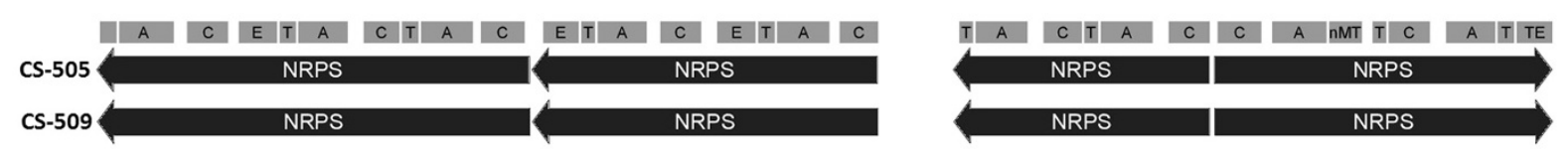

Predicted structure

\section{Legend}
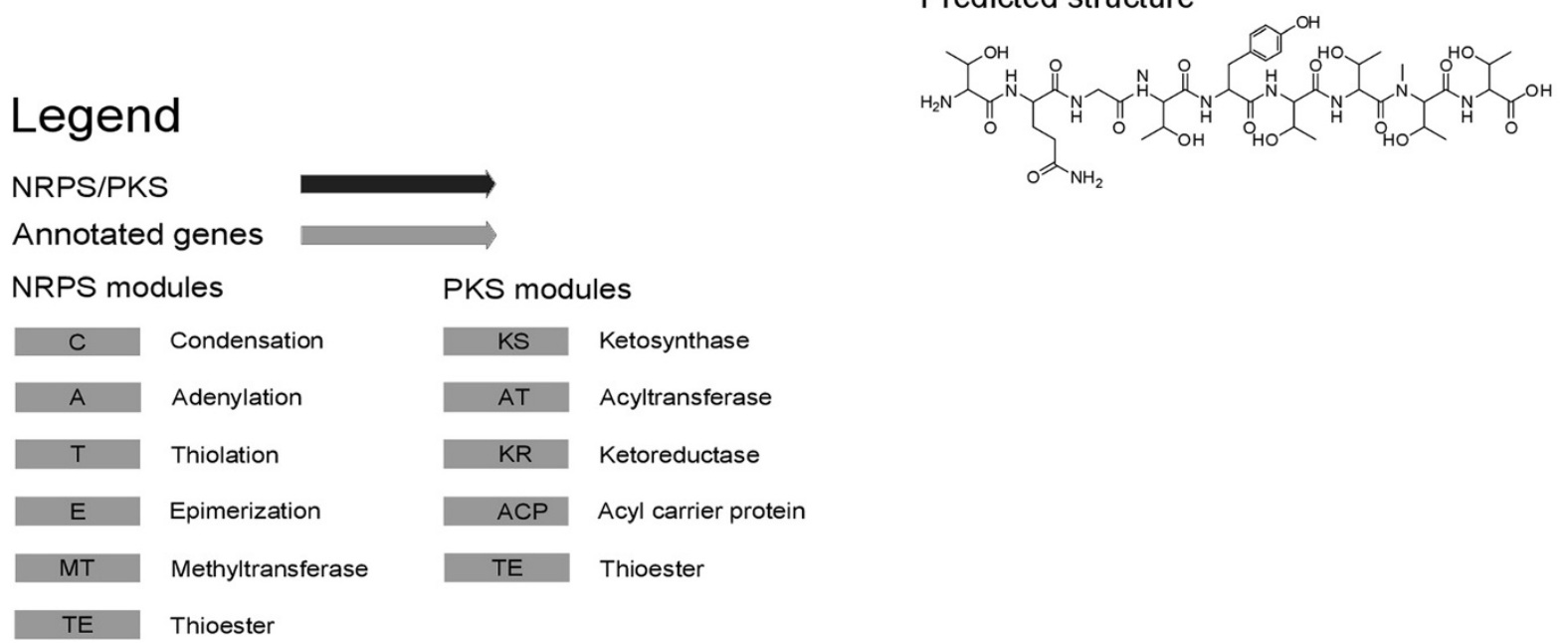

Figure 6 Secondary metabolite clusters identified in the CS-505, CS-506 and CS-509 genomes. The structure prediction was performed using the AntiSMASH program [40], utilising the monomer prediction of NRPSPredictor2 [39]. 
variabilis ATCC 29413 and Cyanothece sp., which possess genes with $82 \%$ and $86 \%$ similarity to NRPS and MFS_1, respectively. The peptide sequence of NRPS1 is also 92\% similar to an NRPS in Raphidiopsis brookii D9, the function of which is unknown. The $R$. brookii D9 NRPS, however, possesses an additional thiolation domain, putatively required for the production of a dipeptide.

The second cryptic cluster identified in this study, NRPS2 occurs in the straight morphotypes, CS-505 and CS-509, but not in the coiled strain CS-506. NRPS2 is approximately $25 \mathrm{~kb}$ in length and comprises 8 ORFs (numbered 2680-2687 in CS-505 and 727-734 in CS509), including a probable hydroxylase and an acyl carrier protein reductase. This cluster is present in the same location in both CS-505 and CS-509 and is flanked by identical genes in both genomes. AntiSMASH analysis suggests that the NRPS2 cluster is involved in the biosynthesis of an octapeptide, which could possibly be the unidentified $C$. raciborskii toxin reported by Falconer et al. 1999 [71]. However, further experimentation, including mutagenesis of the biosynthesis genes or heterologous expression of the complete cluster, combined with chemo-analytical studies are required to verify this.

\section{Genetic divergence and plasticity}

We observed numerous instances of genome duplication in the three study strains, often in multiloci positions. These ranged from photosynthesis-related genes in CS509 to a unique transposase gene, present as ORFs 10 and 487 in CS-506. Further, two identical gene clusters, each comprising five genes encoding hypothetical proteins, which bear $>20 \%$ nucleotide similarity to kinases and a gene encoding a DUF324 protein of unknown function, were also found in the CS-509 genome. The genes that constitute these twin gene clusters also show a high degree of similarity (92\%) to a cluster of hypothetical proteins in Cyanothece sp. PCC 7424.

Nasvall et al. 2012 proposed and subsequently validated the innovation-amplification-divergence (IAD) model, based on a study conducted on over 3,000 generations of the bacterium Salmonella enterica [47]. This theory proffers that genes initially amplify to a higher copy number, following which, one of the extra copies suffer mutations. This eventually leads to divergence of the strain from its co-strains. It is possible that the same phenomenon is in play here, and the different strains of C. raciborskii are gradually diverging through gene duplication, mutation and deletion events.

Further, the highly plastic nature of the $C$. raciborskii genomes is highlighted by the presence of transposase genes, which are found in close proximity to genes with $\mathrm{G}+\mathrm{C}$ contents highly deviant from the average $\mathrm{G}+\mathrm{C}$ content of the C. raciborskii genomes. Additionally, G+ $C$ rich genes were found amidst genes of lower $G+C$ content. This along with the presence of strain-specific genes and integrases reiterates the polymorphic nature of the C. raciborskii genome. Numerous other instances, such as the varying $\mathrm{G}+\mathrm{C}$ content of the cyr gene cluster compared to the flanking hyp gene cluster and the presence of transposase genes adjacent to CRISPR arrays, advocate construction of these genomes via HGT events.

Other cyanobacteria also display evidence of genome plasticity. For example $6.8 \%$ of the Microcystis aeruginosa PCC 7806 genome encodes putative transposases as well as a large number of atypical genes not found in other cyanobacteria [58]. Similarly, a large proportion of the Nostoc punctiforme ATCC 29133 genome encodes unique proteins $(29 \%)$, insertion sites and multilocus repeat sequences [53].

\section{Genes associated with morphological variation between CS-505, CS-506 and CS-509}

In addition to differing in toxin-production, CS-505, CS506 and CS-509 differ in physical morphology; CS-505 and CS-509 are straight, while CS-506 has a coiled trichome [29]. The differing morphologies may be associated with different survival strategies. For example coiled CS506 have been observed to dominate over straight CS505 in environmental blooms, likely in relation to the preference among predators, such as Daphnia, for straight, rather than coiled morphotypes [29]. To better understand the genetics underpinning cell morphology in this species, we examined the three $C$. raciborskii genomes for the presence of morphotype-specific genes. Around 200 genes were common to the straight morphotypes (CS-505, CS-509) but absent from the coiled strain (CS-506). As expected, numerous genes related to cell wall and capsule biosynthesis were exclusive to the straight morphotypes. These include genes responsible for the biosynthesis of capsular and extracellular polysaccharide and murein hydrolases, which play a role in the regulation of cell wall growth in bacteria [32]. Additionally, while the Mre gene that is responsible for cell shape in bacteria was found in all three strains, we observed a total of five SNPs in the gene sequences, three of which were common to the straight morphotypes. The inactivation of the Mre gene in Anabaena sp. PCC 7120 has previously been shown to convert the rod-like shape of the cell to a spherical form [61]. While, further experimentation is required to validate whether the Mre genes in the coiled C. raciborskii strains are active or not, or whether the presence of the SNPs in the straight morphotypes affects the translation of these genes in some way, it is possible that this gene plays a role in $C$. raciborskii morphology. We also found several genes exclusive to the straight morphotypes, many of which are 
putatively involved in cell division, transport, DNA repair, recombination and stress response. Whether or not these genes play a role in cell morphology remains to be determined.

\section{Conclusions}

Our results suggest that CS-505, CS-506 and CS-509 represent distinct ecotypes of $C$. raciborskii, with subtle genetic differences resulting from the niche selective pressures of their specific but geographically similar environments.

This is the first example of genome comparison between closely related toxic and non-toxic $C$. raciborskii strains. As expected, the genomes of these strains were very similar. However, subtle genomic differences alluding to the adaptability of the species were identified. Moreover, numerous examples of strain-specific genes, genes with disparate $\mathrm{G}+\mathrm{C}$ contents, duplicated and/or rearranged genes, as well as transposases and integrases were observed. Taken together, these results underpin the plasticity of the C. raciborskii genome and its potential to evolve in the face of selective pressures. This ability to adapt may help explain the recent invasion of $C$. raciborskii from tropical to temperate climates around the globe.

Most significantly, we demonstrated that toxicity in this species is dependent on possession of the cyr gene cluster, as no other candidate secondary metabolite gene clusters were positively correlated with toxicity. While previous attempts to mutate and thus confirm the role of cyr genes have been unsuccessful, we can now conclude with a high degree of certainty that the cyr cluster is in fact responsible for CYN biosynthesis. Additionally, the non-toxic CS-509 strain lacked the complete suite of cyr genes, but possessed a unique cryptic secondary metabolite gene cluster, NRPS1, the function of which is unknown.

The description of two closely related, but toxigenically different $C$. raciborskii genomes can be considered a starting point for further molecular studies into the regulation of CYN production and its native role in this species. For example, transcriptomic and proteomic analyses examining the effects of chemophysical parameters, such as light, nutrients, and trace elements, on toxic and non-toxic strains can provide insight into the environmental drivers for toxin production. Since the occurrence of this potentially toxic cyanobacterium is on the rise due to increased eutrophication and global warming $[24,72]$, it is imperative to gain a better understanding of the various aspects of its physiology and the integral role played by CYN production. This will further facilitate better prediction and management of harmful cyanobacterial blooms.

\section{Additional files}

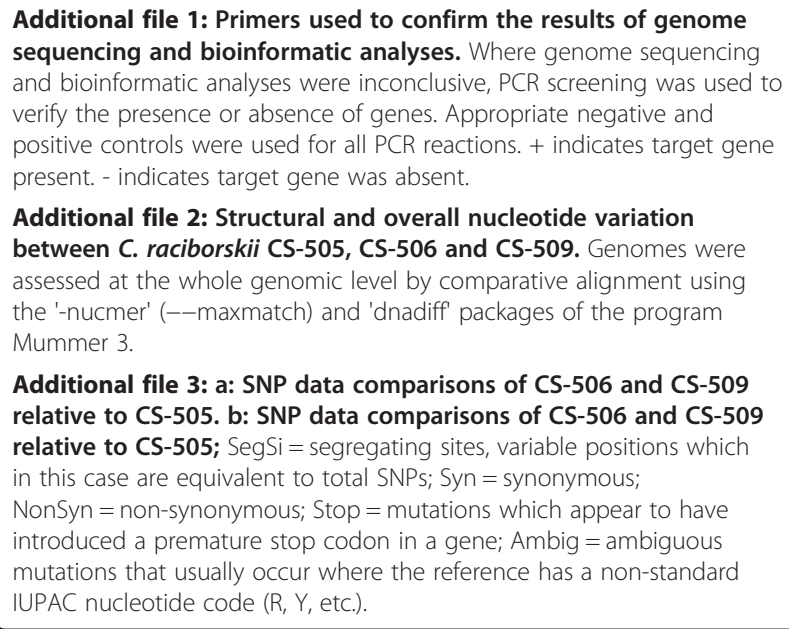

Additional file 2: Structural and overall nucleotide variation between C. raciborskii CS-505, CS-506 and CS-509. Genomes were assessed at the whole genomic level by comparative alignment using the '-nucmer' (--maxmatch) and 'dnadiff' packages of the program Mummer 3.

Additional file 3: a: SNP data comparisons of CS-506 and CS-509 relative to CS-505. b: SNP data comparisons of CS-506 and CS-509 relative to CS-505; SegSi = segregating sites, variable positions which in this case are equivalent to total SNPS; Syn = synonymous; NonSyn = non-synonymous; Stop = mutations which appear to have introduced a premature stop codon in a gene; Ambig = ambiguous mutations that usually occur where the reference has a non-standard IUPAC nucleotide code (R, $Y$, etc.).

\section{Competing interests}

The authors declare that they have no competing interests.

\section{Authors' contributions}

RS carried out the molecular genetics experiments, the bioinformatics analyses, genome assembly and annotation and genome comparisons, as well as the drafting of the manuscript. AJ supervised all the bioinformatics analyses and performed SNP analyses and multiple alignments/comparisons between genomes. RP participated in the NRPS/PKS cluster detection and analyses. BN and MB designed the project and helped in its co-ordination. LP, TD and JM participated in the analyses and interpretation of results and helped draft the manuscript. All authors read and approved the final manuscript.

\section{Acknowledgements}

This work has been supported by an Australian Research Council grant: LP0989475.

\section{Author details}

${ }^{1}$ School of Biotechnology and Bimolecular Sciences, University of New South Wales, 2052 Sydney, NSW, Australia. ${ }^{2}$ Australian Rivers Institute, Griffith University, 4111 Nathan, Queensland, Australia. ${ }^{3}$ Faculty of Veterinary Science, University of Melbourne, Melbourne, Victoria, Australia.

Received: 16 October 2013 Accepted: 14 January 2014 Published: 29 January 2014

\section{References}

1. Rouhiainen L, Sivonen K, Buikema WJ, Haselkorn R: Characterization of toxin-producing cyanobacteria by using an oligonucleotide probe containing a tandemly repeated heptamer. J Bacteriol 1995, 177(20):6021-6026.

2. Santos PVF, Lopes IC, Diculescu VC, Oliveira-Brett AM: DNA - cyanobacterial hepatotoxins Microcystin-LR and Nodularin interaction: electrochemical evaluation. Electroanalysis 2012, 24(3):547-553.

3. Carmichael W, Krishnamurthy T, Beasley V, Min-Juan Y, Bunner DL, Moore RE, Eloff JN, Rinehart K, Falconer I, Runnegar M, Gorham P, Skulberg OM, Harada Kl, Watanabe M: Naming of cyclic heptapeptide toxins of cyanobacteria (blue-green algae). Toxicon 1988, 26(11):971-973.

4. Ohtani C, Ikuko MRE, Runnegar M: Cylindrospermopsin: a potent hepatotoxin from the blue-green alga Cylindrospermopsis raciborskii. J Am Chem Soc 1992, 114(20):7941-7942.

5. Schantz EJ, Ghazarossian VE, Schnoes HK, Strong FM, Springer JP, Pezzanite JO, Clardy J: Structure of saxitoxin. J Am Chem Soc 1975, 97(5):1238-1239.

6. Hyde EG, Carmichael WW: Anatoxin-A(S), a naturally occurring organophosphate, is an irreversible active site-directed inhibitor of acetylcholinesterase. J Biochem Toxicol 1991, 6(3):195-201. 
7. Neilan BA, Dittmann E, Rouhiainen L, Bass RA, Schaub V, Sivonen K, Borner $\mathrm{T}$ : Nonribosomal peptide synthesis and toxigenicity of cyanobacteria. J Bacterio/ 1999, 181(13):4089-4097.

8. Griffiths DJ, Saker ML: The Palm Island mystery disease 20 years on: a review of research on the cyanotoxin cylindrospermopsin. Environ Toxicol 2003, 18(2):78-93.

9. Saker ML, Eaglesham GK: The accumulation of cylindrospermopsin from the cyanobacterium Cylindrospermopsis raciborskii in tissues of the Redclaw crayfish Cherax quadricarinatus. Toxicon 1999, 37(7):1065-1077.

10. Banker R, Carmeli S, Hadas O, Teltsch B, Porat R, Sukenik A: Identification of cylindrospermopsin in Aphanizomenon ovalisporum (Cyanophyceae) isolated from lake Kinneret. Israel. J Phycol 1997, 33(4):613-616.

11. Li R, Carmichael WW, Brittain S, Eaglesham GK, Shaw GR, Liu Y, Watanabe MM: First report of the cyanotoxins cylindrospermopsin and deoxycylindrospermopsin from Raphidiopsis curvata (cyanobacteria). J Phycol 2001, 37(6):1121-1126.

12. Mazmouz R, Chapuis-Hugon F, Mann S, Pichon V, Mejean A, Ploux O: Biosynthesis of cylindrospermopsin and 7-epicylindrospermopsin in Oscillatoria sp. strain PCC 6506: identification of the cyr gene cluster and toxin analysis. Appl Environ Microbiol 2010, 76(15):4943.

13. Spoof L, Berg KA, Rapala J, Lahti K, Lepist L, Metcalf JS, Codd GA, Meriluoto $\mathrm{J}$ : First observation of cylindrospermopsin in Anabaena lapponica isolated from the boreal environment (Finland). Environ Toxicol 2006, 21(6):552-560.

14. Seifert M, McGregor G, Eaglesham G, Wickramasinghe W, Shaw G: First evidence for the production of cylindrospermopsin and deoxycylindrospermopsin by the freshwater benthic cyanobacterium, Lyngbya wollei (Farlow ex Gomont) Speziale and Dyck. Harmful Algae 2007, 6(1):73-80

15. Terao K, Ohmori S, Igarashi K, Ohtani I, Watanabe MF, Harada Kl, Ito E, Watanabe M: Electron microscopic studies on experimental poisoning in mice induced by cylindrospermopsin isolated from blue-green alga Umezakia natans. Toxicon 1994, 32(7):833-843.

16. McGregor GB, Sendall BC, Hunt LT, Eaglesham GK: Report of the cyanotoxins cylindrospermopsin and deoxy-cylindrospermopsin from Raphidiopsis mediterranea Skuja (Cyanobacteria/Nostocales). Harmful Algae 2011, 10:402-410.

17. Schembri MA, Neilan BA, Saint CP: Identification of genes implicated in toxin production in the cyanobacterium Cylindrospermopsis raciborskii. Environ Toxicol 2001, 16(5):413-421.

18. Hawkins PR, Runnegar MT, Jackson AR, Falconer IR: Severe hepatotoxicity caused by the tropical cyanobacterium (blue-green alga) Cylindrospermopsis raciborskii (Woloszynska) Seenaya and Subba Raju isolated from a domestic water supply reservoir. Appl Environ Microbio/ 1985, 50(5):1292-1295.

19. Stucken K, John U, Cembella A, Murillo AA, Soto-Liebe K, Fuentes-Valdvas JJ, Friedel M, Plominsky AM, Vassquez M, Glockner G: The smallest known genomes of multicellular and toxic cyanobacteria: comparison, minimal gene sets for linked traits and the evolutionary implications. PLOS ONE 2010, 5(2):e9235.

20. Padisak J: Cylindrospermopsis raciborskii (Woloszynska) Seenayya et Subba Raju, an expanding, highly adaptive cyanobacterium: worldwide distribution and review of its ecology. Arch Hydrobiol 1997, 107:563-593.

21. Wood SA, Stirling DJ: First identification of the cylindrospermopsinproducing cyanobacterium Cylindrospermopsis raciborskii in New Zealand. NZ J Mar Freshw Res 2003, 37(4):821-828.

22. Hoff-Risseti C, Dorr FA, Schaker PDC, Pinto E, Werner VR: et al.: Cylindrospermopsin and saxitoxin synthetase genes in Cylindrospermopsis raciborskii strains from Brazilian freshwater. PLOS ONE 2013, 8(8):74238.

23. Sinha R, Pearson LA, Davis TW, Burford MA, Orr PT, Neilan BA: Increased incidence of Cylindrospermopsis raciborskii in temperate zones, Is climate change responsible? Water Res 2012, 46(5):1408-1419.

24. Wiedner C, Rucker J, Bruggemann R, Nixdorf B: Climate change affects timing and size of populations of an invasive cyanobacterium in temperate regions. Oecologia 2007, 152(3):473-484.

25. Briand JF, Leboulanger C, Humbert JF, Bernard C, Dufour P: Cylindrospermopsis raciborskii (cyanobacteria) invasion at mid-latitudes: selection, wide physiological tolerance or global warming? J Phycol 2004, 40(2):231e238.
26. Mihali TK, Kellmann R, Muenchhoff J, Barrow KD, Neilan BA: Characterization of the gene cluster responsible for Cylindrospermopsin biosynthesis. Appl Environ Microbiol 2008, 74(3):716-722.

27. Kellmann R, Mihali TK, Jeon YJ, Pickford R, Pomati F, Neilan BA: Biosynthetic intermediate analysis and functional homology reveal a saxitoxin gene cluster in cyanobacteria. Appl Environ Microbiol 2008, 74(13):4044-4053.

28. Stucken K, Murillo AA, Soto-Liebe K, Fuentes-Valdes JJ, Mendez MA, Vasquez M: Toxicity phenotype does not correlate with phylogeny of Cylindrospermopsis raciborskii strains. Syst Appl Microbiol 2009, 32(1):37-48.

29. Saker ML, Neilan BA, Griffiths DJ: Two morphological forms of Cylindrospermopsis raciborskii (cyanobacteria) isolated from Solomon Dam, Palm Island. Queensland. J Phycol 1999, 35(3):599-606.

30. Hu B, Yang G, Zhao W, Zhang Y, Zhao J: MreB is important for cell shape but not for chromosome segregation of the filamentous cyanobacterium Anabaena sp. Mol Microbiol 2007, 63(6):1640-1652.

31. Morin N, Vallaeys T, Hendrick L, Natalie L, Wilmotte A: An efficient DNA isolation protocol for filamentous cyanobacteria of the genus Arthrospira. J Microbiol Methods 2010, 80(2):148-154.

32. Vollmer W, Joris B, Charlier P, Foster S: Bacterial peptidoglycan (murein) hydrolases. FEMS Microbiol Rev 2008, 32(2):259-286.

33. Tillett D, Dittmann E, Erhard M, Von-Dohren H, Borner T, Neilan BA Structural organization of microcystin biosynthesis in Microcystis aeruginosa PCC7806: an integrated peptide-polyketide synthetase system. Chem Biol 2000, 7(10):753-764

34. Ishida K, Welker M, Christiansen G, Cadel-Six S, Bouchier C, Dittmann E, Hertweck C, Tandeau de Marsac N: Plasticity and evolution of Aeruginosin biosynthesis in cyanobacteria. App/ Environ Microbiol 2009, 75(7):2017-2026.

35. Markowitz V, Korzeniewski F, Palaniappan K, Szeto E, Werner G, Padki A, Zhao X, Dubchak I, Hugenholtz P, Anderson I, et al: The integrated microbial genomes (IMG) system. Nucleic Acids Res 2006, 34:344-348.

36. Aziz R, Bartels D, Best A, DeJongh M, Disz T, Edwards R, Formsma K, Gerdes S, Glass E, Kubal M: The RAST Server: rapid annotations using subsystems technology. BMC genomics 2008, 9(1):75-

37. Delcher A, Harmon D, Kasif S, White O, Salzberg S: Improved microbial gene identification with GLIMMER. Nucleic Acids Res 1999, 27(23):4636-4641.

38. Besemer J, Borodovsky M: GeneMark: web software for gene finding in prokaryotes, eukaryotes and viruses. Nucleic Acids Res 2005, 33(2):451-454.

39. Ansari M: NRPS-PKS: a knowledge-based resource for analysis of NRPS/ PKS megasynthases. Nucleic Acids Res 2004, 32(2):405.

40. Medema MH, Blin K, Cimermancic P, DeJager V, Zakrzewski P, Fischbach MA Weber T, Takano E, Breitling R: antiSMASH: rapid identification, annotation and analysis of secondary metabolite biosynthesis gene clusters in bacterial and fungal genome sequences. Nucleic Acids Res 2011, 39:339-346.

41. Quevillon E, Silventoinen V, Pillai S, Harte N, Mulder N, Apweiler R, Lopez R: InterProScan: protein domains identifier. Nucleic Acids Res 2005, 33:W116-W120.

42. Punta M, Coggill PC, Eberhardt RY, Mistry J, Tate J, Boursnell C, Pang N, Forslund K, Ceric G, Clements J, et al: The Pfam protein families database. Nucleic Acids Res 2012, 40(D1):D290-D301.

43. Altschul SF, et al: Basic local alignment search tool. J Mol Biol 1990, 215:403-410.

44. Li R, Li Y, Kristiansen K, Wang J: SOAP: short oligonucleotide alignment program. Bioinformatics 2008, 24(5):713.

45. Delcher A, Salzberg SL, Phillippy AM: Using MUMmer to identify similar regions in large sequence sets. Curr Protoc Bioinformatics 2003, 10(3). Chapter 10, unit 10.3.

46. Li H, Durbin R: Fast and accurate long-read alignment with BurrowsWheeler transform. Bioinformatics 2010, 26(5):589-595

47. Edgar RC: MUSCLE: multiple sequence alignment with high accuracy and high throughput. Nucleic Acid Res 2004, 32(5):1792-1797.

48. Langmead B, Salzberg SL: Fast gapped-read alignment with Bowtie 2. Nat Methods 2012, 9:357-359.

49. Volkman SK: A genome-wide map of diversity in Plasmodium falciparum. Nature Genet 2007, 39:113-119.

50. Li H, Handsaker B, Wysoker A, Fennell T, Ruan J, Homer N, Marth G, Abecasis G, Durbin R, 1000 Genome Project Data Processing Subgroup: The Sequence alignment/map (SAM) format and SAMtools. Bioinformatics 2009, 25(16):2078-2079.

51. Aziz R, Bartels D, Best A, DeJongh M, Disz T, et al: The RAST server: Rapid annotations using subsystems technology. BMC Genomics 2008, 9(1):75. 
52. Shi T, Bibby TS, Jiang L, Irwin AJ, Falkowski PG: Protein interactions limit the rate of evolution of photosynthetic genes in cyanobacteria. $\mathrm{Mol}$ Biol Evol 2005, 22(11):2179-2189.

53. Meeks J, Elhai J, Thiel T, Potts M, Larimer F, Lamerdin J, Predki P, Atlas R: An overview of the genome of Nostoc punctiforme, a multicellular, symbiotic cyanobacterium. Photosynth Res 2001, 70(1):85-106.

54. Su Z, Olman V, Xu Y: Computational prediction of Pho regulons in cyanobacteria. BMC Genomics 2007, 8:156-158.

55. Naylor GW, Addlesee HA, Gibson LCD, Hunter CN: The photosynthesis gene cluster of Rhodobacter sphaeroides. Photosynth Res 1999, 62(2):121-139.

56. Thiel T, Lyons E, Erker J: Characterization of genes for a second Mo-dependent nitrogenase in the cyanobacterium Anabaena variabilis. J Bacteriol 1997, 179(16):5222-5225.

57. Herrero A, Muro-Pastor AM, Flores E: Nitrogen control in cyanobacteria. J Bacteriol 2001, 183(2):411-425.

58. Frangeul L, Quillardet P, Castets AM, et al: Highly plastic genome of Microcystis aeruginosa PCC 7806, a ubiquitous toxic freshwater cyanobacterium. BMC Genomics 2008, 9:274.

59. Rounge TB, Rohrlack T, Tooming-Klunderud A, Kristensen T, Jakobsen KS: Comparison of cyanopeptolin genes in Planktothrix, Microcystis, and Anabaena Strains: Evidence for independent evolution within each genus. Appl Environ Microbiol 2007, 73(22):7322-7330.

60. Tanaka M, Moriya Y, Goto S, Kanehisa M: Analysis of a lipid biosynthesis protein family and phospholipid structural variations. Jap Soc Bioinformatics 2010, 22:191-201.

61. Hu B, Yang G, Zhao W, Zhang Y, Zhao J: MreB is important for cell shape but not for chromosome segregation of the filamentous cyanobacterium Anabaena sp. PCC 7120. Mol Microbiol 2007, 63(6):640-652.

62. Alexova R, Haynes PA, Ferrari BC, Neilan BA: Comparative protein expression in different strains of the bloom-forming cyanobacterium Microcystis aeruginosa. Mol cell proteomics 2011, 10(9):3749-3765.

63. Jiang Y, Xiao P, Yu G, Sano T, Pan Q, Li R: Molecular basis and phylogenetic implications for deoxy-cylindrospermopsin biosynthesis in Raphidiopsis curvata (cyanobacteria). Appl Environ Microbiol 2012, 78(7):2256-2263.

64. Stuken A, Campbell RJ, Quesada A, Sukenik A, Dadheech PK, Wiedner C: Genetic and morphologic characterization of four putative cylindrospermopsin producing species of the cyanobacterial genera Anabaena and Aphanizomenon. J Plankton Res 2009, 31(5):465-480.

65. Tamagnini P, Leitão E, Oliveira P, Ferreira D, Pinto F, Harris DJ, Heidorn T, Lindblad P: Cyanobacterial hydrogenases: diversity, regulation and applications. FEMS Microbiol Rev 2007, 31(6):692-720.

66. Stuken A, Jakobsen KS: The cylindrospermopsin gene cluster of Aphanizomenon sp. strain 10E6: organization and recombination. Microbiol 2010, 156(8):2438-2451.

67. Johnson TL, Palenik B, Brahamsha B: Characterization of a functional vanadium-dependent bromoperoxidase in the marine cyanobacterium Synechococcus Sp. CC93111. J Phycol 2011, 47(4):792-801.

68. Moustafa A, Loram JE, Hackett JD, Anderson DM, Plumley FG, Bhattacharya D: Origin of Saxitoxin biosynthetic genes in cyanobacteria. PLOS ONE 2009, 4(6):e5758.

69. Christiansen G, Molitor C, Philmus B, Kurmayer R: Nontoxic strains of cyanobacteria are the result of major gene deletion events induced by a transposable element. Mol Biol Evol 2008, 25(8):1695-1704.

70. Neilan BA, Pearson LA, Moffitt MC, Mihali TK, Kaebernick M, Kellmann R, Pomati F: The genetics and genomics of cyanobacterial toxicity. In: Cyanobacterial Harmful Algal Blooms: State of the Science and Research Needs, Chapter 17. Adv Exp Med Biol 2008, 619:417-452.

71. Falconer IR, Hardy SJ, Humpage AR, Froscio SM, Tozer GJ, Hawkins PR: Hepatic and renal toxicity of the blue-green alga (cyanobacterium) Cylindrospermopsis raciborskii in male Swiss albino mice. Environ Toxicol 1999, 14(1):143-150.

72. Paerl HW, Fulton RS: Ecology of harmful cyanobacteria. In Ecology of Harmful Algae. Edited by Graneli E, Turner JT. Berlin Heidelberg: Springer; 2006:95-109.

doi:10.1186/1471-2164-15-83

Cite this article as: Sinha et al:: Comparative genomics of

Cylindrospermopsis raciborskii strains with differential toxicities. BMC

Genomics 2014 15:83.

\section{Submit your next manuscript to BioMed Central and take full advantage of:}

- Convenient online submission

- Thorough peer review

- No space constraints or color figure charges

- Immediate publication on acceptance

- Inclusion in PubMed, CAS, Scopus and Google Scholar

- Research which is freely available for redistribution 